\title{
Ovarian Serous Cystadenoma, Torsion, Salpingitis and Schistosomiasis in a Nigerian. Case Report
}

\author{
Wilson Onuigbo ${ }^{1 *}$ and Deirdre Twomey ${ }^{2}$ \\ ${ }^{1}$ Medical Foundation and Clinic, Nigeria \\ ${ }^{2}$ Mater Hospital, Nigeria
}

Submission: June 22, 2018; Published: July 06, 2018

*Corresponding author: Wilson Onuigbo, Medical Foundation and Clinic, Enugu, Nigeria, Email: wilson.onuigbo@gmail.com

Abstract

The rural woman in a developing country bears the family's load. The recourse when sickness strikes is to a rural hospital, especially a Missionary one. This case illustrates the enormity of the possible diseases, the combination here being ovarian serous cystadenoma, torsion and pyogenic salpingitis with schistosomiasis. Salpingo ophorectomy led to uneventful recovery.

Keywords: Abdominal pain; Ovary; Torsion; Salpingitis; Schistosomiasis; Missionary Hospital; Operation; Uneventful recovery; Nigeria

\section{Introduction}

Of late years, the British scene was clouded by those disparaging histology reports required by distant hospitals [1]. Elsewhere [2], one of us examined the falsity of this issue with reference to the developing community known as the Igbos of Nigeria [3]. Accordingly, a case is presented showing the variety of the abdominal conditions met in a young woman for whom salpingo ophorectomy was the answer from the junior author (DT) in the hinterland Mater Hospital, Afikpo. The interconnected etiologic elements were unraveled by the senior author (WO) at a Reference Pathology Laboratory situated in the Capital City, Enugu, Nigeria.

\section{Case Report}

EC, a 25-year-old para 1 patient, came to Mater Hospital, Afikpo. Menses was normal. She was experiencing severe abdominal pain and constipation for 3 days running. On examination by the junior author (DT), this revealed a tender mass in the left iliac fossa. Hence, acute abdomen due to organ torsion was diagnosed. Laparotomy revealed both torsion and infection. Peritonitis was apparent and the omentum was adherent in the pelvis. The enlarged torsed left ovary was situated in the Pouch of Douglas. The uterus appeared normal. Therefore, salpingo ophorectomy was performed. Her recovery was uneventful.

The specimens were examined at the Reference Pathology Laboratory at Enugu, the Regional Capital City. In the main, there was a $14 \times 10 \times 5 \mathrm{~cm}$ cystic mass, which was largely smooth surfaced and was attached to a $2.5 \mathrm{~cm}$ tube measuring $10 \mathrm{~cm}$ long. This tube was distended in parts with gelatinous and greenish purulent looking matter. On section, the cyst contained watery brownish fluid. Its wall was paper thin for the most part. Microscopy revealed serous cystadenoma, acute salpingitis and the ovarian typical ova of Schistosoma haematobium. See Figure 1.

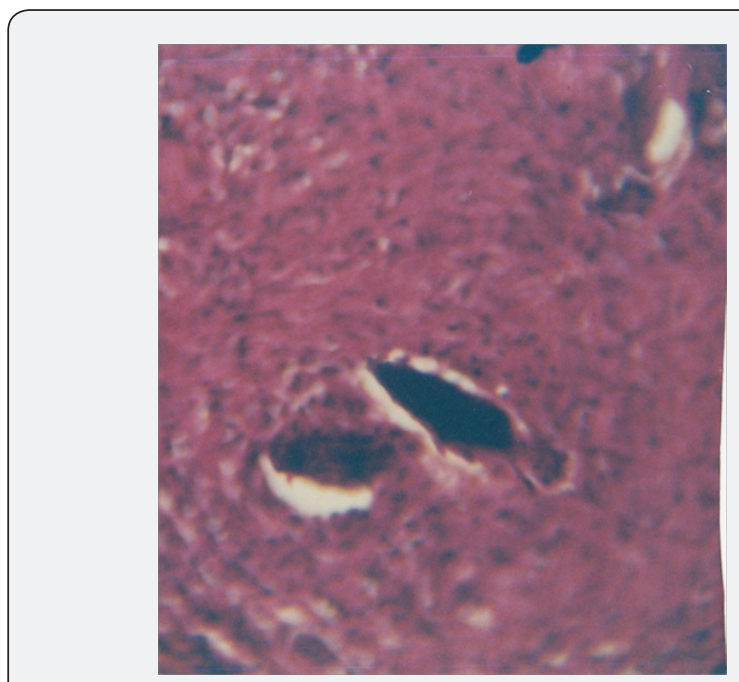

Figure 1: Section showing terminal spine of the Schistosoma haemorrhagica egg with foreign body giant cell nearby.

\section{Discussion}

The serous cystadenoma is an interesting lesion of the ovary [4]. It has been viewed from such angles as hugeness in not only an adolescent girl [5] and a young woman [6] but also in a postmenopausal woman [7]. Its striking associations have been 
recorded with fibrothecoma [8], fibroma [9], and contralateral ovary which was torsed [10].

The above cases were reported from India, Turkey and Iran. Therefore, our case stands out from Nigeria in exhibiting the combination with not only torsion and salpingitis but also schistosomiasis. This particular worm infestation has been reported locally as regards the appendix [11] and urinary bladder [12,13].

\section{Conclusion}

Our case merits documentation as regards ovarian serous cystadenoma and its associated lesions. However, concerning the advancing edge of science, it suffices to exemplify with molecular genetic analysis [14].

On a mundane note, this paper exemplifies the work done by Missionary Physicians in the hinterlands of a developing community. In this context, co-authorship was affected earlier concerning such topics as schistosomiasis in ovarian thecoma [15], carcinoma-in-situ of the vagina [16], uterine procidentia [17], and abdominal paragonimiasis [18].

In the final analysis, Birmingham (UK) authors emphasized that the establishment of a histopathology data pool facilitates epidemiological analysis [19]. Their concept was verified in the present paper which depended on such a data pool in a developing community.

\section{References}

1. Lilleyman J (2002) From the president. Bull Roy Coll Pathol 117: 2-3.

2. Onuigbo WIB, Mbanaso AU (2005) Urban histopathology service for a remote Nigerian hospital. Bulletin of the Royal College of Pathologists 132: $32-34$.

3. Basden GT (1966) Niger Ibos. Cass, London, UK.

4. Dayanand RK, Waje A (2015) Rare presentation of serous cystadenoma as menorrhagic cyst. Obstet Gynecol Intl J 2(4): 00045.

5. Ciftci I, Sekmenli T, Ugras S (2013) Ovarian huge serous cystadenoma in adolescent girl: A case report. Nat J Med Res 3(2): 187.
6. Agah J, Jararzadeh RE, Kamalimanesh B, Abdizadeh MF, Jalilian AR (2015) Mismanagement of a huge ovarian serous cystadenoma in a young girl; a Case report. J Midwifery Repro Hlth 3(1): 315-317.

7. Sujatha VV, Babu SC (2009) Giant ovarian serous cystadenoma in a postmenopausal woman: a case report. Cases J 2: 7875.

8. Chandanwale SS, Pal SS, Kumar HB, Sammi AB (2015) Serous cystadenoma and fibrothecoma: A rare combination in collision tumor of ovary with pseudo-meigs syndrome. J Pathol Trans Med 49(2): 163166.

9. Alyer D, Gul C, Celayir AC, Sahin D (2015) A case of ovarian torsion with a serous cyst and coexisting serous cystadenoma in the contraleteral ovary. J Pediat Surg Specialt 9(2): 1-52.

10. Jayalakshmy PS, Poothiode U, Krishna G, Jayalakshmy PL (2012) Ovarian fibroma with serous cystadenoma-an unusual combination: A case report. Case Rep Obstet Gynecol 2012: 641085.

11. Onuigbo WIB (1985) Appendiceal schistosomiasis: method for classifying oviposition and inflammation. Dis Colon Rect 28(6): 397398.

12. Onuigbo WIB (2005) Carcinoma of urinary bladder in a region of low schistosomiasis. J Coll Med 10(1): 3-5.

13. Onuigbo WIB, Ukeje MAS, Ezeome ER (1995) Urinary bilharziasis among Nigerian school children: a study in the Agulu Lake Basin, Anambra State of Nigeria. W Afr J Med 14: 233-237.

14. Cheng EJ, Kurman RJ, Wang M, Oldt R, Wang BG, et al. (2004) Molecular genetic analysis of ovarian serous cystadenomas. Lab Invest 84(6): 778-784.

15. Onuigbo WIB, Twomey D (1978) Schistosomiasis of ovarian thecoma. Med J Zambia 12: 27-28.

16. Onuigbo WIB, Twomey D (2017) Carcinoma-in-situ of the vagina in a developing community. Intl J Case Stud Cancer Res 1(3): 63.

17. Onuigbo WIB, Twomey D (2015) Uterine procidentia in a 15-year-old girl in Nigeria. J Med Diagnos Mthds S2: 001.

18. Onuigbo WIB, Twomey D (2016) Clinical suspicion of abdominal paragonimiasis was confirmed after emergency laparotomy together with unfolding of coexisting endomatriosis. J Med Diagnos Mthds 5: 195.

19. Macartney JC, Rollaston TP, Codling BW (1980) Use of a histopathology data pool for epidemiological analysis. J Clin Pathol 33(4): 351-355.

\section{Your next submission with Juniper Publishers will reach you the below assets}

- Quality Editorial service

- Swift Peer Review

- Reprints availability

- E-prints Service

- Manuscript Podcast for convenient understanding

- Global attainment for your research

- Manuscript accessibility in different formats

( Pdf, E-pub, Full Text, Audio)

- Unceasing customer service

Track the below URL for one-step submission https://juniperpublishers.com/online-submission.php 